\section{DE DE GRUYTER}

OPEN
Przedsiębiorczość i Zarządzanie Entrepreneurship and Management University od Social Sciences Publishing House

ISSN 1733-2486

Volume XVI, Issue 2, pp. 157-170

DOI 10.1515/eam-2015-0024

Barbara Kamińska

University of Social Sciences

\title{
Kaizen as a Method of Management Improvement in Small Production Companies
}

\begin{abstract}
"Quality is not everything but everything is nothing without quality". The famous quotation from K. Ishikawa brings to our attention the fact that nowadays quality is one of strategic concepts from the point of view of functioning of companies, especially production-oriented ones. The lack of quality often eliminates a product from the basket of potential further choices. That means that quality is a prerequisite in the contemporary, highly competitive and saturated market. In order to ensure quality, enterprises introduce various concepts and methods to support quality management. They include, among others, the kaizen philosophy, which allows to minimize unnecessary actions (losses). It is especially recommended to small firms as an inexpensive method assuring high quality of products because they are constantly improved, which, in turn, guarantees maintaining a high position among competitors. This article aims to introduce the concept of kaizen by describing how it works and considering whether it can be successful in Polish companies.
\end{abstract}

Key words: quality management, improvement, kaizen philosophy.

\section{Introduction}

Contemporary enterprises, especially production-oriented ones, operate in a very demanding environment with one of the requirements being quality as, according to Flynn, only well-designed high-quality products, combined with quality integrating supporting processes, allow for competitive advantage [Flynn, Schroeder, Sakakibara 1994]. A key to achieve the highest quality by an 
enterprise is to introduce management through quality. That ensures effective solutions eventually translating into customer satisfaction. The process should be supported by other methods and tools which were developed to meet the very needs of quality improvement such as, among others, the kaizen method, whose philosophy consists of willingness to constantly improve processes taking place in a company. In a nutshell, kaizen is a never-ending process of improvement and change for the better.

\section{Quality in a Production Company}

The concept of quality has accompanied humankind since as early as the ancient times [Karaszewski 2009, p. 13]. In its broad sense, quality can be understood as a degree to which a certain good/service, phenomenon, process or organization adapts to expectations of an experiencing subject [Lisiecka 2001, Skrzypek 2001]. Thus, quality concerns not only tangible products but also services or other objects and can be assessed through a set of both measurable and unmeasurable factors. Therefore, quality is a term occurring in various areas of human activity, hence being interpreted in a variety of ways. While discussing quality, it seems justified to quote definitions by well-known classics mentioned by specialist literature, such as, among others: Deming, Juran, Crosby or Feigenbaum. According to the first of the above classics, quality is perceived as a predicted degree of singularity and reliability of a product with simultaneously maintaining the lowest possible costs and adapting to the requirements of the market [Mroczko 2011, p. 21], which also entails an orientation change (customer orientation). The concept is based on controlling the quality of processes and products performed in a specific cycle of both management and execution actions called the Deming circle. Juran another outstanding persona among quality consultants - defined quality as capability of a good or service to meet set objectives, e.g. quality is "a degree to which a specific product meets the needs of a specific buyer", quality is "a degree to which a specific product class is potentially able to satisfy consumers" [Karaszewski 2009, p. 4]. Juran's concept, the so called "Juran trilogy" refers to basic and auxiliary processes which focus on three fundamental aspects [Gołębiowski, Janasz, Prozorowicz 2000, pp. 42-43]: quality planning, quality control and quality improvement. Juran believed that quality should be taken into account at each stage in product life from its design to measuring customer satisfaction. Crosby presented quality as the consistence of a product with customer requirements in respect of use, production and quality of the product. He based his concept on the so called four absolutes [Gajewski 2007, pp. 31-32]: quality as conformity with specification and 
not a good product; quality achieved through prevention and not evaluation; quality measured as the cost of non-conformity with specification and not indices; quality standard meaning absence of defects with no place for allowable quality level. Feigenbaum understood quality as a set of product or service characteristics related to marketing, design, production and servicing, thanks to which products customers use meet their expectations. He also thought that quality arises from proper management rather than being a solely technical action [Mroczko 2011, p. 21]. When analysing the above definitions, it is impossible not to observe that they all aim at total customer satisfaction. In deliberations of contemporary authors, quality is also considered in an evaluative way. They give three important reasons for that: "Firstly, it determines ability to gain competitive advantage being, through its very nature, a category which ought to be considered in a comparative manner. Secondly, it is only in that manner that value delivered to customers can be assessed based on the evaluation of quality. Thirdly, quality is treated as a basic tool in creating value for the customer" [Haffer 2003, p. 59]. Therefore, as rightly written by the author, quality should be perceived as total quality in that context. That means that quality perceived by the customer will take the form of quality of the company's market offer which is created, along with products and their features, by other determinants. As it can be seen, quality may be regarded as an absolute as well as relative concept. Hence, it is recommended to diagnose and gather those determinants by defining quality from the point of view of the customer.

Therefore, total quality considered in the context of functioning of an enterprise, especially a production one, is vital in evaluating the enterprise or its particular products in the market. In short, it is among key factors determining the market success of a company.

When going deeper into the discussion of the raised issues, it ought to be added that quality also translates into efficiency as it results in a reduced number of products returned by dissatisfied customers and, most importantly, higher quality means lower costs for an enterprise. Regrettably, low quality is tantamount to a high number of returns, warranty costs or costs of lawsuits brought by dissatisfied customers [Griffin 2004, pp. 689-690]. Thus, for production entities, high product quality at possibly "low" costs is a crucial competitive factor. 


\section{Figure 1. Seeking an optimum quality level}

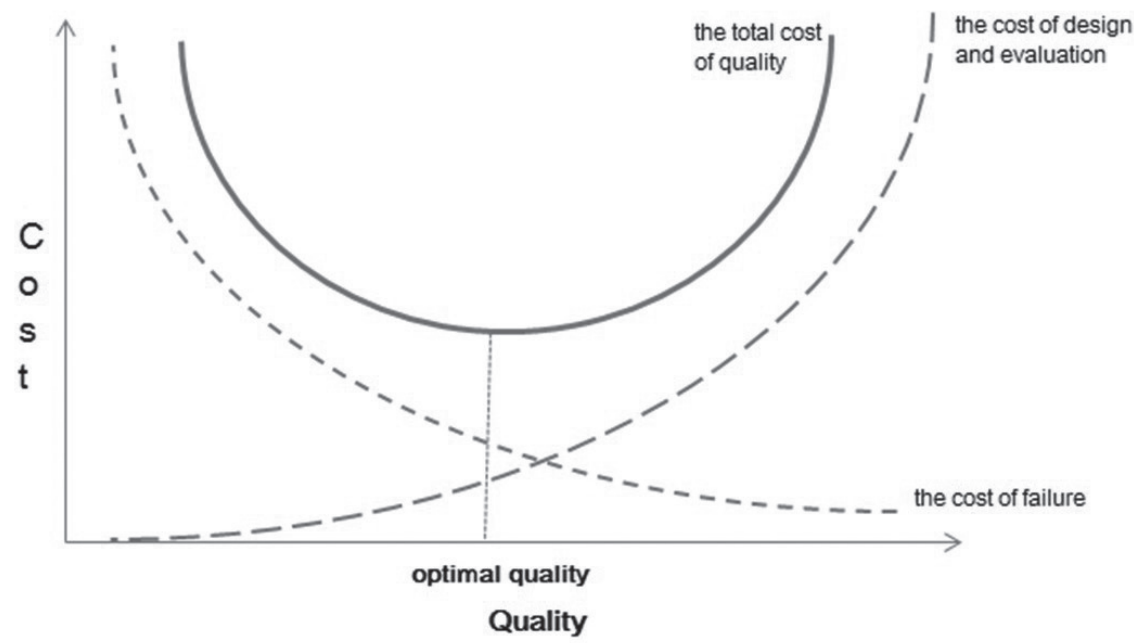

Source: Waters 2001.

When discussing costs, what else should be mentioned is lost revenues due to the loss of existing or potential customers and, consequently, the loss of a potential increase in turnover as a result of the failure to deliver goods or services at a quality level required by the market. An example may be the loss of a customer to competitors owing to excessively long order fulfilling period [Bank 1997, pp. 112-113]. Therefore, it is of the utmost importance to appropriately manage quality, which has, hence, become an integral part of the production process rather than only one of its functions as it eventually translates into customer satisfaction.

\section{Management through Quality}

As already mentioned, modern enterprise management is characterized by a multitude of concepts. They include those oriented at the enterprise management process, management through quality being one of them. That, nevertheless, requires a set of actions and systemic solutions encompassing virtually all areas of enterprise functioning. Only such an approach allows to achieve the highest quality possible in a broad sense [Griffin 2004, p. 691]. The quality management system is a set of coordinated actions concerning managing and supervising an organization, where such actions usually include establishing a policy of quality and goals which regard quality, quality planning, quality controlling, quality assurance and quality improvement [Hamrol 2005, 
p. 122]. It should be added, however, that such a system requires a complex approach which can be guaranteed by the Total Quality Management (TQM) concept. That consists in involving all areas of enterprise activity and cooperation of all organization members at every level of its functioning. Attention is brought to that by Feigenbaum who believes that a whole organization, its departments, structures and production workers should necessarily be involved in the process of improving quality [Borys, Rogala 2002]. The diagram below shows the most important dimensions of complex quality management.

\section{Diagram 1. Dimensions of complex quality management}

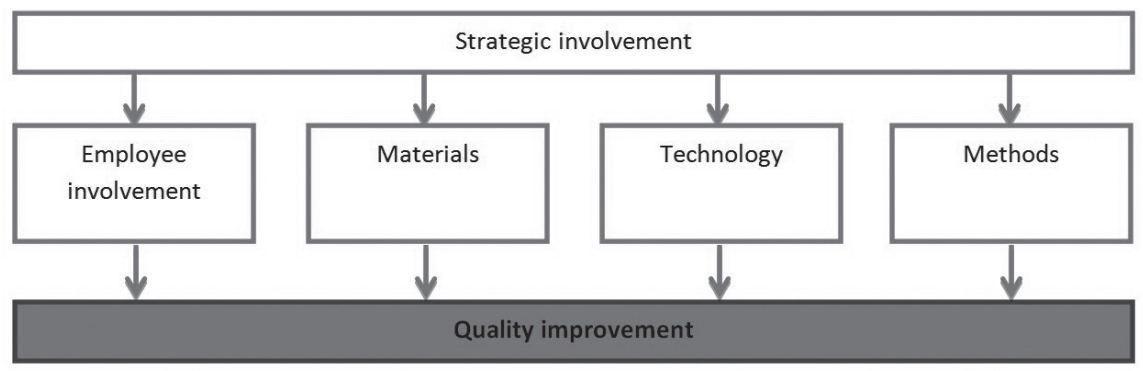

Source: Griffin 2004.

As illustrated by the diagram, the first and seemingly most important TQM dimension is involvement of senior management whose task, in turn, is to initiate, support and organize all actions for quality improvement. That also or, perhaps, mainly concerns creating organizational culture as the concept assumes that improved efficiency, and thus competitiveness of enterprises, derives from creating pro-quality culture which presumes that every human and his or her action in an organization affects quality in a specific way [Steinbeck 1998, p. 27]. Other dimensions are materials, technology and work organization methods. When appropriately remodelled, all those areas can result in quality improved from the point of view of the final customer of an enterprise [Griffin 2004, pp. 691-692]. TQM applies numerous methods supporting complex quality management. Among the main methods, specialist literature mentions kaizen whose central idea is common involvement in quality issues, and thus constant elimination of losses and deficiencies in all aspects of an organization's activity. Similarly to a majority of quality concepts, kaizen originated from Japan, too. It is a philosophy derived from Japanese practice and culture of management, and is strongly associated with the country's culture. The application of the method is discussed in the next chapter. 


\section{Essence of Kaizen}

In Japanese kaizen means constant improvement of all organization members as well as processes, products and any improvement actions, and entails relatively low costs [Strumiłło 2010, p. 185]. Kaizen is the development of the fifth of Deming's fourteen principles which assumes that causes of occurring problems should constantly be looked for and eliminated [Ćwikliński, Obora 2009 , p. 17]. It is a method consisting of setting tasks for employees to be performed and information concerning expected results. At the same time, goals should be divided into stages possible to be gradually completed. In the kaizen method, it is crucial that, in contrast to the Western style enterprise management strategy (following set instructions), employees of companies managed according to the kaizen philosophy are encouraged to submit all ideas aimed at improving existing standards [http://www.biznesologia.pl]. That is so because it is assumed that it is employees who have constant and direct contact with a situation that may be the cause of problems and kaizen allows to eliminate mistakes and imperfections in the functioning of an organization. In short, an organization's path to success leads through improving its internal processes and involvement of all its members [Mroczko 2011, p. 290]. It ought to, however, be added that results of those actions are not immediately visible and need some time to be seen. Therefore, kaizen is called a method of small steps that should lead to constantly getting closer to perfection. One of kaizen's messages says that no day should pass without making an improvement in a company, which is enabled by introducing the kaizen philosophy based on three pillars, i.e. [Dąbrowska 2011]: preventing waste, workplace organization and standardization.

Kaizen considers to be a loss for those actions that, from the point of view of the customer, do not add any value to final products. According to the kaizen model, as many as seven main types of waste can be distinguished: overproduction, inventories, long waiting time, defects and their correction, improperly planned production process, transport and unnecessary motion. It is worth adding that it is overproduction that is considered the most harmful type of waste leading to capital freezing, use of energy, human labour and unnecessary storage costs. However, the other mentioned types, which do not directly add value to a manufactured product or offered service, may also result in losses in an enterprise. In turn, using the language of accounting definitions, every loss is a negative financial result of an enterprise, hence excessive waste ought to be prevented. Nevertheless, it should be added that kaizen deems some losses necessary as they secure, e.g., the production cycle, but also those can be considerably reduced by introducing appropriate creative 
improvements, thanks to the $5 \mathrm{~S}$ method consisting in regular learning of standardization and discipline. The applied $5 \mathrm{~S}$ principle should aim to increase productivity of work thanks to its better organization at the workstation. In order to streamline work organization processes, standards should be established that would be helpful in minimizing occurring mistakes.

The above discussion indicates that kaizen allows to cheaply eliminate or minimize hidden costs resulting from excessive waste; improve operations aimed at adding value in production so that the customer gets the highest quality product, at the lowest cost and in the shortest possible time; minimize unnecessary actions and work delays so that employees can work in an easier and uninterrupted way; and many more that, in consequence, will enable to easier achieve a stable position among competitors in the market. Admittedly, with small steps but with a guarantee that goods will always be of high quality because they are constantly improved, which, in turn, ensures maintaining a high position among competitors.

\section{Kaizen Introduction Process}

As already mentioned, kaizen is inexpensive management methodology more and more often recommended to the SME sector and showing that small but regularly introduced improvements may, eventually, produce greater effects than e.g. major reorganization of a company that entails high costs. Kaizen introduction in an enterprise does not require large financial outlays (expensive technologies or huge investments) but only constant involvement and effort of all organization members as the implementation of kaizen should take place at the level of all areas of management and among all who have direct contact with the final product. That allows line workers to affect e.g. the manner in which they perform their work. The process, however, requires support of senior management who are responsible for providing appropriate conditions of work and culture conducive to constant improvement. That can be facilitated by the process approach promoted by the Japanese among whom orientation towards processes and, through them, results prevails. They see in small changes, often not entailing any expenses, a considerable source of saving an organization's resources [Imai 1992].

The process of applying the kaizen method consists of several stages. They are listed below [Karaszewski 2009, p. 231].

- Defining an area for improvements,

- Analysing and selecting key problems,

- Identifying reasons for improvements,

- Planning preventive measures, 
- Implementation,

- Comparing results,

- Standardization.

While introducing kaizen, it is very important to monitor changes but support by managers is also crucial in order to maintain permanence and continuity of improvements. It is recommended to carry out improvement projects by taking small steps. The first step is to look for problems and thus form a habit in employees to seek better ways of performing their tasks in order to streamline them. Both problems and their causes are best identified by encompassing performed work within procedures and conducting detailed analysis. The next step is to put forward an idea, i.e. propose methods of solving a problem that have not been used before. The final step is to implement the idea and assess its effectiveness [Karaszewski 2009, p. 231].

Taking the above tips while introducing kaizen will simultaneously enable to eliminate concerns that it will be received sceptically or indifferently by employees, and, at the same time, will allow to totally or partly eliminate mistakes, which will translate into benefits for workers and consumers.

Furthermore, successful improvement project implementation, especially in its final phase, is affected by good team cooperation. It is assumed that all team members are equal irrespective of their positions in an organization's structure. Participants should, first and foremost, be oriented towards cooperation and gain knowledge from experience of others rather than compete, be open to changes, have a positive attitude and respect one another. However, practice shows that there are problems in Polish enterprises with sharing ideas etc., which is why it is important to train employees, determine the form and procedure of submitting ideas, verifying and rewarding them.

Major systems worth of application in order to successfully introduce the kaizen method are listed below [http://www.eksportuj.pl]:

- The Just-In-Time system is oriented towards eliminating all types of actions which do not add value and creating the lean production system that will be flexible enough to adjust to fluctuations in customer orders.

- Total Productive Maintenance focuses on improving the quality of machines. TPM strives to maximize equipment efficiency through a complex system of preventive actions to extend the life-span of devices. While TQM involves all individuals in a company, TPM involves all on the shop floor.

- Policy Deployment - although the kaizen strategy aims to introduce improvements, it effects may be limited if everyone is involved in 
kaizen for kaizen itself with no objective aim in mind. The management should establish clear goals to guide people and make sure that they provide leadership in all kaizen actions aimed at achieving the set goals. In practice, the kaizen strategy requires careful supervision of implementation.

- The suggestion system - works as an integral part of kaizen oriented towards each employee. It emphasizes benefits resulting from boosted morale and positive participation of employees in small informal volunteer interdepartmental groups organized in order to perform specific tasks in the shop floor environment. Their task is to deal not only with issues connected with quality but also such that concern cost, safety and productivity.

\section{Kaizen in a Production Company - Case Study}

\section{$X$ Company Activity}

The analysed company specializes in the manufacture of turned and milled products made using state-of-the-art technologies mostly for the automotive and engineering industries. The company mission is to provide customers with the highest quality products and maintaining its high competitive position in the market. Employees know that the proper understanding of customers' needs and offering them individualized products better than those of competitors gives the company an advantage.

A crucial element in the company's activity policy is to streamline processes, improve and update employees' knowledge, which translates into the quality of elements made. Currently, the company manufactures about 1000 elements. An important, or probably the most important, assumption in to constantly broaden the range of offered products. To that end, the company tries and invests in state-of-the-art machines, technologies and modern provisioning processes. Thanks to that, it fulfils orders according to customer requirements. The care of the quality of products and customer service is the pride of the company. The enterprise holds a quality certificate allowing to streamline internal processes and creates its external image.

At present, the company has 30 employees, including: qualified staff and top-class specialists in human resource management, marketing, logistics, engineering and technology as well as machining. Along with the above-mentioned human resource, the enterprise has other resources necessary to carry out activity such as: modern shop floors, storehouses and modern machines. Thanks to the use of innovative technologies and high-quality equipment, the 
company is able to manufacture complicated elements consistent with customers' documentation.

\section{Quality Management System in the Company}

In order to satisfy the customer, the company pursues a Quality Management Policy based on constant improvement of process and product quality. Process management is among important tools of the Quality Management System in the company. The company focuses on managing processes on the scale of the whole enterprise. Process owners were provided with access to resources and information necessary to support the course and monitoring of those processes. 
Table 1. Processes carried out in the $\mathrm{X}$ company

\begin{tabular}{|c|c|c|c|}
\hline Process name & $\begin{array}{l}\text { Document } \\
\text { type }\end{array}$ & $\begin{array}{l}\text { Document } \\
\text { identification } \\
\text { number }\end{array}$ & Document title \\
\hline \multicolumn{4}{|c|}{ A-System process } \\
\hline \multirow{4}{*}{$\begin{array}{l}\text { Maintenance and } \\
\text { improvement } \\
\text { SZJ }\end{array}$} & \multirow{4}{*}{ Procedure } & PMM4201 & $\begin{array}{l}\text { Document and record } \\
\text { supervision }\end{array}$ \\
\hline & & PMM8201 & Internal audits \\
\hline & & PMM8301 & $\begin{array}{l}\text { Inconsistent product } \\
\text { supervision }\end{array}$ \\
\hline & & PMM8501 & $\begin{array}{c}\text { Corrective and preventive } \\
\text { measures }\end{array}$ \\
\hline \multicolumn{4}{|c|}{ B - Main processes } \\
\hline \multirow{5}{*}{ Metal working } & \multirow{5}{*}{ Process card } & KP7201 & Offers and orders \\
\hline & & KP7501 & $\begin{array}{c}\text { Technology } \\
\text { documentation preparing }\end{array}$ \\
\hline & & KP7502 & $\begin{array}{l}\text { Production process } \\
\text { supervision }\end{array}$ \\
\hline & & KP7503 & $\begin{array}{l}\text { Material and product } \\
\text { storage }\end{array}$ \\
\hline & & KP8202 & Product quality inspection \\
\hline \multicolumn{4}{|c|}{ C-Supporting processes } \\
\hline \multirow{4}{*}{$\begin{array}{c}\text { Provision and } \\
\text { management } \\
\text { of resources }\end{array}$} & \multirow{4}{*}{ Process card } & KP7401 & $\begin{array}{c}\text { Purchases and supplier } \\
\text { qualification }\end{array}$ \\
\hline & & KP6201 & Personnel management \\
\hline & & KP6301 & Infrastructure supervision \\
\hline & & KP7601 & $\begin{array}{l}\text { Measuring equipment } \\
\text { supervision }\end{array}$ \\
\hline
\end{tabular}

Source: the company's documentation. 
The company's Director as the Management Representative is responsible for supervising the internal audit process but, in order to efficiently carry out the QMS auditing process, the Director uses services of an external consultant appointed to conduct internal audits in the company.

\section{Kaizen Philosophy Application in the Company}

Process owners are obliged to implement necessary actions in order to achieve planned results and constantly improve processes. One of the actions was kaizen introduction, i.e. enabling employees to present their ideas, corrections or improvements in order to increase productivity and quality of work.

At the same time, being aware of difficulties occurring at the implementation of the method of ideas, connected with the need to change workers' attitude and gain their complete acceptance and sense of full participation in the re-organization, a system of rewards for ideas was applied. Despite obstacles and the fact that the process of kaizen philosophy introduction is painstaking and long-lasting, requiring involvement and appropriate attitude of all employees of the company, it can currently be said that the system took roots in the enterprise and positively affected many of its aspects. Employees are involved in applying new ideas and consider the project one of more important ideas conducive to the improvement of processes taking place in the company.

The introduction of the kaizen philosophy allowed, making modest financial outlays, to involve all employees in the process of improving workstations, increasing productivity, improving relations among employees, shortening order completion time and thus increasing the quality of the final product.

Benefits of implementing kaizen in the company include, among others:

- Shortened order completion time,

- Product quality improvement,

- Improved working conditions (increased productivity of workers, shortened time needed to perform some operations),

- Reduced number of customers' complaints,

- Reduced production losses, numbers of mistakes and defects,

- Enhanced responsibility of workers for the level of quality, enabling employees' development, broadening the scope of their knowledge.

External benefits are: meeting requirements and expectations of the customer, enhancing competitive advantage, increasing trust among partners and suppliers, improving the company's image in its broader and immediate environment.

It should, however, be added that kaizen does not dramatically change existing conditions - changes are small and aimed at ensuring gradual improve- 
ment. It is a slow and long-term process of changes, often characterized by excessive painstakingness; although it is not so important for smaller firms, it is a huge challenge to large companies; the board of directors and managers have to focus on every detail, which requires great perceptiveness and coordination. It is also more difficult to reach each and every employee. Another problem is the lack of appropriate organizational culture in European companies and, regrettably, the success of kaizen, as already mentioned, is to a large extent dependent on understanding the philosophy of its functioning in an enterprise.

\section{Summary}

Constant improvement is a permanent feature of every quality management system. What guarantees constant improvement is a series of actions taken inside an organization. One of those actions is to introduce the kaizen philosophy, which allows to identify what kind of problems occur, whether they recur and what improvement tasks should be undertaken.

The introduction of well-tried quality management systems in a company enables the company to be positively perceived by customers as reliable and caring about constant development of the final product quality. Based on opinions of people responsible for the functioning and improvement of quality management in the company, it should be stated that the proper application of the system provides the company with considerable competitive advantage and allows to better understand problems occurring in the company, thanks to which it is easier to manage it and lay good foundations for its further development.

\section{References}

Bank J. (1997), Zarządzanie przez jakość, Wydawnictwo Gebethner \& Ska, Warszawa.

Borys T., Rogala P. (2002), Armand Vallin Feigenbaum, „Problemy Jakości”, nr 12. Ćwikliński M., Obora H.(2009), Metody TQM w zarządzaniu firma. Praktyczne przyktady za-stosowań, Poltext, Warszawa.

Dąbrowska A. (2011), KAIZEN: Matymi krokami do wielkich zmian, „Manager”, nr 6.

Flynn B.B., Schroeder R.G., Sakakibara S. (1994), A framework for Quality Management Research and an Associated Measuring Instrument, "Journal of Operations Management", 11.

Gajewski A. (2007), Wstęp do zarządzania jakościa, Wydawnictwo Małopolskiej Wyższej Szkoły Ekonomicznej w Tarnowie, Tarnów. 
Gołębiowski M., Janasz W., Prozorowicz M. (2000), Polityka projakościowa $w$ przedsiębiorstwie, Wydawnictwo Naukowe Uniwersytetu Szczecińskiego, Szczecin.

Griffin R.W. (2004), Podstawy zarzadzania organizacjami, Wydawnictwo Naukowe PWN, Warszawa.

Haffer R. (2003), Systemy zarządzania jakościa w budowaniu przewag konkurencyjnych przedsiębiorstw, Wyd. Uniwersytetu Mikołaja Kopernika w Toruniu, Toruń.

Hamrol A. (2005), Zarządzanie jakościa z przyktadami, Wydawnictwo Naukowe PWN, Warszawa.

http://www.biznesologia.pl/ kaizen-czyli-kropla-ktora-drazy-skale.html, 10.09.2014. http://www.eksportuj.pl/, 15. 09. 2014.

Imai M. (1992), Kaizen. Tajemnica sukcesu Japonii, ZETOM, Warszawa.

Karaszewski R. (2009), Nowoczesne koncepcje zarządzania jakościa, Toruń.

Lisiecka K. (2001), Filozofia jakości życia a metody zarządzania przedsiębiorstwem, „Problemy Jakości”, nr 1.

Mroczko F. (2011), Zarządzanie jakościa, Prace Naukowe Wałbrzyskiej Wyższej Szkoły Zarządzania i Przedsiębiorczości, Wałbrzych.

Skrzypek E. (2001), Ekonomiczne aspekty jakości życia, „Problemy Jakości”, nr 1.

Strumiłło J. (2010), Koncepcja TBM i kaizen [w:] M. Czerska, A. Szpitter (red.), Koncepcje zarzadzania. Podręcznik akademicki, Wydawnictwo C.H. Beck, Warszawa.

Waters D. (2001), Zarzadzanie operacyjne. Towary i ustugi, Wydawnictwo Naukowe PWN, Warszawa. 